\title{
Bioremediation of Zearalenone by using Lactobacillus acidophilus in albino rats bodies (in vivo)
}

\author{
Sami A Ali, Ibrahim H Jasim, Ali M Nasir, Ali K Mshatat, Shahad H Hamadi, Rusul N Khadam, \\ Zahraa J Rasol \& Meyameen H Mahdi
}

\begin{abstract}
Objective This study aimed to evaluate the efficiency of Lactobacillus acidophilus to reduce zearalenone toxicity in vital systems of albino white rats.

Methods Fusarium graminearum isolate was tested to produce zearalenone toxin. L. acidophilus was used to reduce the toxin in rats. This ability was studied by many parameters such as biochemical and physiological parameters in addition to histological study.

Results The results showed that L. acidophilus had the ability to reduce zearalenone toxicity. L. acidophilus had the ability to raise $\mathrm{Hb} 11 \mathrm{~g} / \mathrm{dl}$ in blood of animals that was treated with zearalenone only to $13.06 \mathrm{~g} / \mathrm{dl}$ in animal's blood that was treated with zearalenone + L. acidophilus. As well as the number of red blood cells in animals blood treated with these treatment was $6.62 \times 10^{12} \mathrm{cell} / \mathrm{L}$. L. acidophilus reduces the toxicity of zearalenone through its ability to reduce the number of platelets to normal levels.

Conclusion L. acidophilus had a role in repeated biochemical parameters to normal levels. Total protein rose to $6.6 \mathrm{~g} / \mathrm{dl}$ in animal's blood treated with zearalenone + L. acidophilus compared with these levels in blood of control group. Also GPT and sugar levels in animal blood that was treated with zearalenone $+L$. acidophilus were at normal level. Histological study proved that $L$. acidophilus had the ability to protect liver, kidney, and uterus from the toxicity of zearalenone.

Keywords Lactobacillus acidophilus, Fusarium graminearum, zearalenone
\end{abstract}

\section{Introduction}

Zearalenone $(\mathrm{ZEN})$ is a mycotoxin by virtue of its estrogenic effects, and produced by certain various species of Fusarium genus, including F. culmorum, F. equiseti, F. graminearum and F. moniliforme and is associated mainly with cereal crops, in particular, maize. Although the mycotoxin is probably most common in maize, very high level $(11.15 \mu \mathrm{g} / \mathrm{kg})$ can also be found in other cereals.

The effective dose $\left(\mathrm{ED}_{50}\right)$ of $\mathrm{ZEN}$ is very low $(0.2 \mu \mathrm{g} / \mathrm{kg})$, and suspected to cause human diseases, including premature puberty syndrome as well as hyper estrogenic in farm animals. ${ }^{2}$ Collins et al. $^{3}$ showed that ZEN caused diseases in heart, brain, kidney and ovary of rats when treated with ZEN. ${ }^{4}$ It also found a correlation between ZEN excited in blood plasma of women and breast cancer.

There are many species of bacteria used in bioremediation of mycotoxins, as Lactobacillus acidophilus which reduced the toxicity of ochratoxin A in white rats. ${ }^{5}$ Sezer et al. (2013) found that L. plantarum has the ability to reduce the amounts of aflatoxin B1 (AFB1) with $46 \%$ while L. lactis with $27 \%$.

There are methods to control mycotoxins in food and feeds including physical methods, chemical methods and biological controls. But there is no antitoxin to control ZEN toxin. So the aim of this study was to evaluate the efficiency of L. acidophilus to reduce ZEN toxicity in some vital systems of albino white rats.

\section{Materials and Methods}

This study was conducted in the clinical laboratory of College of Applied Medical Sciences, University of Karbala, Iraq.

1. Preparation of potato dextrose agar: This medium was prepared according to the procedures of the manufacturing company (HIMEDIA, India).
2. Preparation of ZEN stander: It was prepared by adding $4 \mathrm{ml}$ of chloroforme to $1 \mathrm{mg}$ of $\mathrm{ZEN}$, the concentration of mycotoxin (ZEN) becomes $250 \mu \mathrm{g} / \mathrm{ml}$.

3. Testing the ability of $F$. graminearum to produce ZEN: We obtained one F. graminearum isolate from toxins. This testing was conducted according to Ishii et al. $(1974)^{7}$ and Scott et al (1981).

4. Efficiency of $L$. acidophilus to reduce ZEN toxicity: This study was conducted as follows:

i. Isolation and diagnosis of $L$. acidophilus: $L$. acidophilus was isolated according to a study by Macfaddin (2000), ${ }^{9}$ and L. acidophilus was diagnosed by VITEK 2 compact.

ii. Preparation of bacterial inoculum: Preparation of L. acidophilus inoculum was done according to the method by Williams et al. (1983). ${ }^{10}$

5. Preparation of laboratory animals

A. Twelve white female rats with similar ages were divided into four groups, each group included three animals.

B. Each group of animals were treated as follows:

i. First group of animals were treated only with ZEN (6 mg/kg animal weight).

ii. Second group of animals were treated with L. acidophilus inoculum $(1 \mathrm{ml} / \mathrm{kg})$. After 24 hours it was treated with zearalenone $(6 \mathrm{mg} / \mathrm{kg}$ animal weight).

iii. Third group of animals were treated only with L. acidophilus inoculum $(1 \mathrm{ml} / \mathrm{kg})$.

iv. Fourth group of animals were treated only with distil water (control treatment).

Treatment of animals continued till 14 days. At the end of the prescribed period, animals were sacrificed after being

Department of Clinical Laboratories, College of Applied Medical Sciences, Karbala University, Karbala, Iraq.

Correspondence to Ibrahem Haidar Jasim (email: ibrahem_som@yahoo.com).

(Submitted: 01 December 2014 - Revised version received: 25 January 2015 - Accepted: 28 January 2015 - Published online: Winter 2015)

J Cont Med Sci | Vol. 1, No. 1, Winter 2015:21-25 
treated with chloroform and anatomy was done by opening the abdominal cavity. Blood was drawn by a stab heart (heart puncture).

One part of the blood was sterilised without anti-clotting materials and the other part was poured into test tubes which contained anti-coagulant materials, and physiological and biochemical tests were conducted. Also samples taken from liver, kidney, spleen and ovaries were saved in formalin (10\%).

\section{Biochemical Parameters}

The level of glucose, total protein and glutamate pyruvate transaminase (GPT) enzymes in the blood serum of animals were estimated and treated as instructed by manufacture's guidelines (spectrum; SAE, Egypt).

a. Estimate the level of glucose in the blood

b. Estimate the level of total protein in the blood

c. Estimate the level of GPT enzyme in the blood

\section{Physiological Parameters}

Physiological parametric study included to calculate the amount of haemoglobin (Hb), red blood cells (RBCs), monocytes and platelets by using of HumaCount 60TS, Germany.

\section{Histological Study}

The tissue sections were prepared in the Laboratory of Applied Medical Sciences and followed the method of Bancroft and Stevens (1892). ${ }^{11}$

\section{Statistical Analysis}

The design of experiment was carried out as complete random design (CRD) with single factor, and the mean was compared according to least signification difference (LSD) at 0.05 probability level. ${ }^{12}$

Table 1. Effect of $L$. acidophilus on some physiological parameters in the blood of albino white rats that were treated with zearalenone

\begin{tabular}{lcccc}
\hline Treatment & $\begin{array}{c}\mathbf{H b} \\
\mathbf{g} / \mathbf{d l}\end{array}$ & $\begin{array}{c}\mathbf{R B C} \\
\mathbf{c e l l} / \mathbf{I}\end{array}$ & $\begin{array}{c}\mathbf{M O N} \\
\text { cell/ } \mathbf{m m}^{\mathbf{3}}\end{array}$ & $\begin{array}{c}\mathbf{P L T} \\
\mathbf{c e l l} / \mathbf{m m}^{3}\end{array}$ \\
\hline ZEN & 11 & $4.7 \times 10^{12}$ & $0.97 \times 10^{3}$ & $1400 \times 10^{3}$ \\
ZEN+LBA & 13.06 & $6.62 \times 10^{12}$ & $0.48 \times 10^{3}$ & $860 \times 10^{3}$ \\
LBA & 13.2 & $5.76 \times 10^{12}$ & $0.67 \times 10^{3}$ & $768 \times 10^{3}$ \\
Control & 12.06 & $6.29 \times 10^{12}$ & $0.41 \times 10^{3}$ & $883 \times 10^{3}$ \\
LSD (0.05) & 2.2 & 0.6 & 0.5 & 164 \\
\hline
\end{tabular}

LBA: L. acidophilus; LSD: least signification difference; MON: monocytes; PLT: platelet; RBC: red blood cell; ZEN: zearalenone.

\section{Results}

1. Testing the ability of F. graminearum isolates to produce ZEN

The results of chemical analysis; thin layer chromatography (TLC); showed that $F$. graminearum isolates have ability to produce ZEN. ${ }^{13}$

\section{Physiological parameter}

a. Haemoglobin: ZEN caused to lower the $\mathrm{Hb}$ amount to $11 \mathrm{gm} / \mathrm{dl}$ in animal blood that was treated with ZEN whereas the level for this parameter in control group was $12.65 \mathrm{gm} / \mathrm{dl}$. The amount of $\mathrm{Hb}$ rose to $13.06 \mathrm{gm} / \mathrm{dl}$ in animal blood that was treated with toxin and bacterium (ZEN + L. acidophilus). Also the amount of $\mathrm{Hb}$ increased to 13.2 $\mathrm{gm} / \mathrm{dl}$ in animals that were treated with only bacterium L. acidophilus) (Table 1).

This result was in agreement with a study by AL-Khafaji (2014) $)^{13}$ who found that ZEN decreased $\mathrm{Hb}$ amount to $10.8 \mathrm{~g} /$ $\mathrm{dl}$ while these amount in control treatment group was $12.3 \mathrm{~g} / \mathrm{dl}$. AL-Fatlawi $(2014)^{14}$ reported that when treated with F. foetens it produced toxic metabolites and produced less amount of $\mathrm{Hb}$.

$\mathrm{AFB} 1$ and $\mathrm{B} 2$ decreases $\mathrm{Hb}$ amount in rats to $8.6 \mathrm{~g} / \mathrm{dl}$ and $7.3 \mathrm{~g} / \mathrm{dl}$, respectively, whereas the amount of $\mathrm{Hb}$ in blood of control animals group was $13 \mathrm{~g} / \mathrm{dl}$.

Kubena et al. (1987) $)^{15}$ found that secondary metabolic products of the fungi has the ability to bind with blood proteins which is responsible for the biosynthesis of the $\mathrm{Hb}$ causing the lowest number of RBCs.

b. RBCs: The results showed that toxin ZEN reduces the number of RBCs to $4.7 \times 10^{12}$ cell $/ \mathrm{mm}^{3}$ in animals treated only with toxin compared with control group $\left(6.29 \times 10^{12}\right.$ cell/l), while the number of $\mathrm{RBC}$ in the blood of experimental animal that was treated with ZEN + L. acidophilus was $6.62 \times 10^{12}$ cell/l (Table 1).

AL-Khafaji (2014) ${ }^{13}$ found that ZEN reduced the number of RBCs to 4.7 $\times 10^{12} \mathrm{cell} / \mathrm{l}$ while it was $5.8 \times 10^{12} \mathrm{cell} / \mathrm{l}$ in the control group. Also Moura et al $(2004)^{16}$ reported that ochratoxin A decreased the count of RBC when treated with ZEN.

c. Monocytes: The results as shown in Table 1 revealed that ZEN toxin treatment caused an increase in monocytes number to $0.97 \times 10^{3}$ cell/ $\mathrm{mm}^{3}$ while the number of these cells were $0.41 \times 10^{3} \mathrm{cell} / \mathrm{mm}^{3}$ ) in the control group. At the same time, ZEN + L. acidophilus treatment reduced the number of monocytes to normal level in animal blood $\left(0.48 \times 10^{3} \mathrm{cell} / \mathrm{mm}^{3}\right)$. Also the numbers of monocytes in animal blood that was treated with only L. acidophilus were at normal level (Table 1). AL-Hashemi (2014) $)^{17}$ showed that AFB1 caused an increase in monocytes numbers to $1.3 \times 10^{3}$ cell/ $\mathrm{mm}^{3}$ while it was $0.04 \times 10^{3} \mathrm{cell} / \mathrm{mm}^{3}$ in animals that were treated with AFB1.

d. Platelets: ZEN toxin affected the number of platelets, this parameter raised to $1400 \times 10^{3} \mathrm{plat} / \mathrm{mm}^{3}$ in animals that were treated with only ZEN compared with control group $\left(883 \times 10^{3} \mathrm{plat} / \mathrm{mm}^{3}\right)$. $\mathrm{ZEN}+$ L. acidophilus treatment decreased the number of platelets to $860 \times 10^{3}$ plat/ $\mathrm{mm}^{3}$ (normal level), while it was $768 \times 10^{3}$ plat $/ \mathrm{mm}^{3}$ in animal that were treated with only bacterium (Table 1). AL-Hashemi $(2014)^{17}$ showed that AFB1 caused increase in number of platelets in the blood of animals. Also Samuel et al. (2009) ${ }^{18}$ found that AFB1 increased the platelets in chicken blood to $135 \times 10^{3} \mathrm{plat} / \mathrm{mm}^{3}$.

\section{Biochemical parameters}

a. Total protein: Biochemical blood parameters affected by ZEN caused decreased level of total proteins from $7.1 \mathrm{~g} /$ $\mathrm{dl}$ in animal blood of control treatment to $5.3 \mathrm{~g} / \mathrm{dl}$ in animal blood of ZEN treatment, while L. acidophilus and ZEN treatment raised the level of protein in blood to 6.6 $\mathrm{g} / \mathrm{dl}$ (Table 2). This result agreed with the study by AL-Khafaji (2014) ${ }^{13}$ who found that total protein level decreased in blood of animals that were treated with ZEN. He also found that (ZEN + Bacillus subtilis) treatment raised total proteins in animals treated with these toxins.

b. GPT: ZEN caused raise of GPT in blood of animals that were treated with ZEN to $19 \mathrm{U} / \mathrm{l}$ compared with control treatment (15 U/l). $\mathrm{ZEN}+L$. 


\section{Table 2. Effect of $\boldsymbol{L}$. acidophilus on some biochemical parameters of albino white rats treated with zearalenone}

\begin{tabular}{lccc}
\hline Treatment & $\begin{array}{c}\text { Total protein } \\
(\mathbf{g} / \mathbf{d l})\end{array}$ & $\begin{array}{c}\text { GPT } \\
(\mathbf{U} / \mathbf{L})\end{array}$ & $\begin{array}{c}\text { Glucose } \\
(\mathbf{m g} / \mathbf{d l})\end{array}$ \\
\hline ZEN & 5.3 & 19 & 165 \\
ZEN + LBA & 6.6 & 11.6 & 90 \\
Bacteria & 6 & 12.3 & 119 \\
Control & 7.1 & 15 & 97 \\
LSD (0.05) & 1.6 & 9.5 & 43 \\
\hline
\end{tabular}

GPT: glutamic pyruvic transaminase; LBA: L. acidophilus; LSD: least signification difference; ZEN: zearalenone.

acidophilus treatment decreased the level of GPT to $11.6 \mathrm{U} / 1$ in blood of animals (Table 2).

This result agreed with Ali and Kazem (2012) ${ }^{19}$ who found that compound produced by $B$. holmii caused an increase of GPT level to $33 \mathrm{U} / \mathrm{l}$. Also
AL-Khalidy $(2012)^{20}$ showed that $G$. candidium and $G$. penicillatum produced toxic phenolic compounds which raised the level of GPT to $44 \mathrm{U} / \mathrm{l}$. AL-Kelkali $(2005)^{21}$ reported that $F$. solani filtrate raised the level of GPT in blood of rats when treated with these filtrates. $F$. graminearum filtrate raised the level of GPT in the blood of mice. These filtrates caused degradation of liver cells membrane and lysis of liver cells causing exit of these enzymes to blood.22

c. Sugar: On the other hand, ZEN raised sugar in animal to $165 \mathrm{mg} / \mathrm{dl}$ compared with control treatment (97 $\mathrm{mg} / \mathrm{dl}$ ), while the level of sugar in blood of animals when treated with ZEN $+L$. acidophilus was $90 \mathrm{mg} / \mathrm{dl}$ (Table 2). Increase in the level of sugar in animals blood belong to ZEN able to decrease of hexokinase and glycogen phosphatase level in blood of animals causing defect in sugar and glycogen metabolism.

\section{Histological study}

The results of our a current study agree with AL-Khafaji (2014) ${ }^{13}$ who found that ZEN caused pathogenic changes in liver, intestine, and spleen. Also he found that $B$. subtilis was able to reduce the toxicity of ZEN in vital systems of rats (Fig. 1-4).

This study indicated that $L$. acidophilus had the ability to protect the vital systems of animal from toxic effect of ZEN (Figs. 1C-4C).

Also L. acidophilus did not cause pathogenic changes in organs of the animals (Figs. 1D-4D). This result agrees with AL-Khafaji (2014) ${ }^{13}$ who found that ZEN caused pathogenic changes in liver, intestinal and spleen. He also found that B. subtilis was able to reduce the toxicity of $\mathrm{ZEN}$ in vital systems of rats. Al-Khalidy (2010) ${ }^{24}$ reported that the metabolics of G. canidium and G. pencillium caused abnormal changes in liver and kidney.
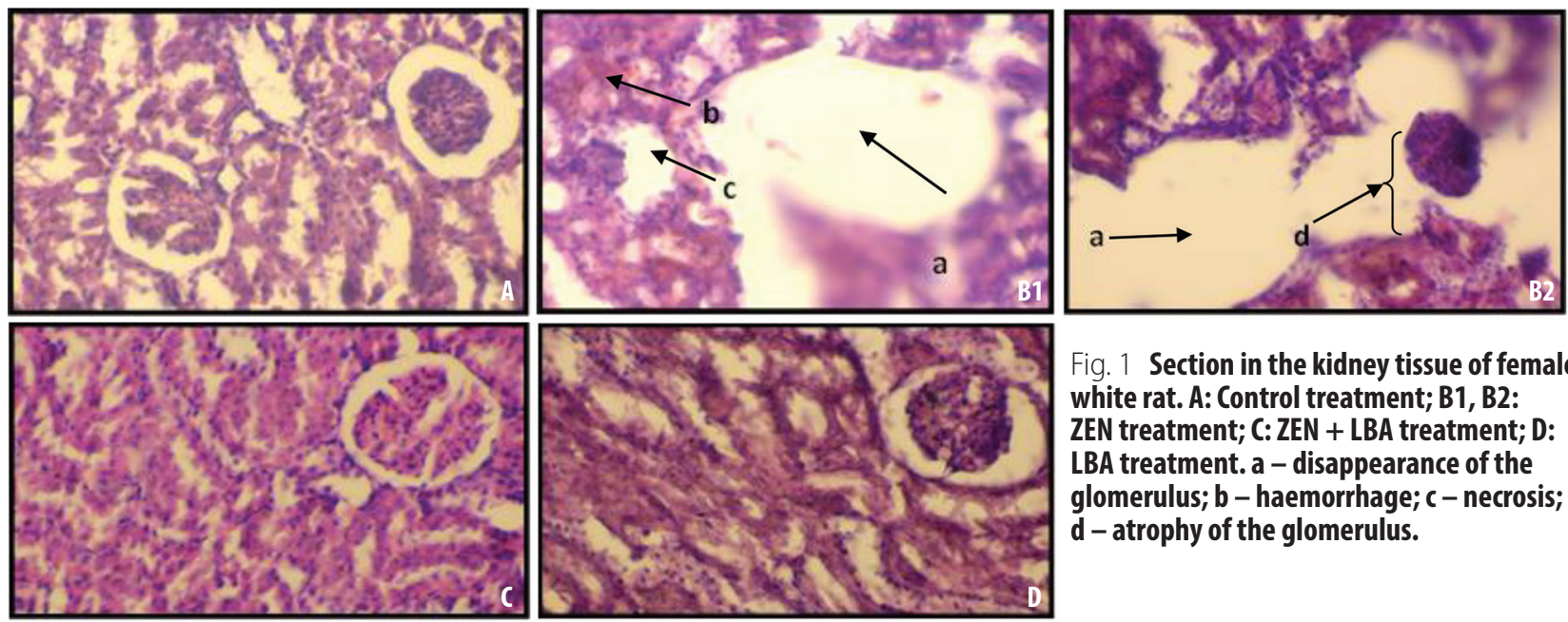

Fig. 1 Section in the kidney tissue of female white rat. A: Control treatment; B1, B2:

ZEN treatment; C: ZEN + LBA treatment; D:

LBA treatment. a - disappearance of the glomerulus; $b$ - haemorrhage; c - necrosis; $\mathrm{d}$ - atrophy of the glomerulus.
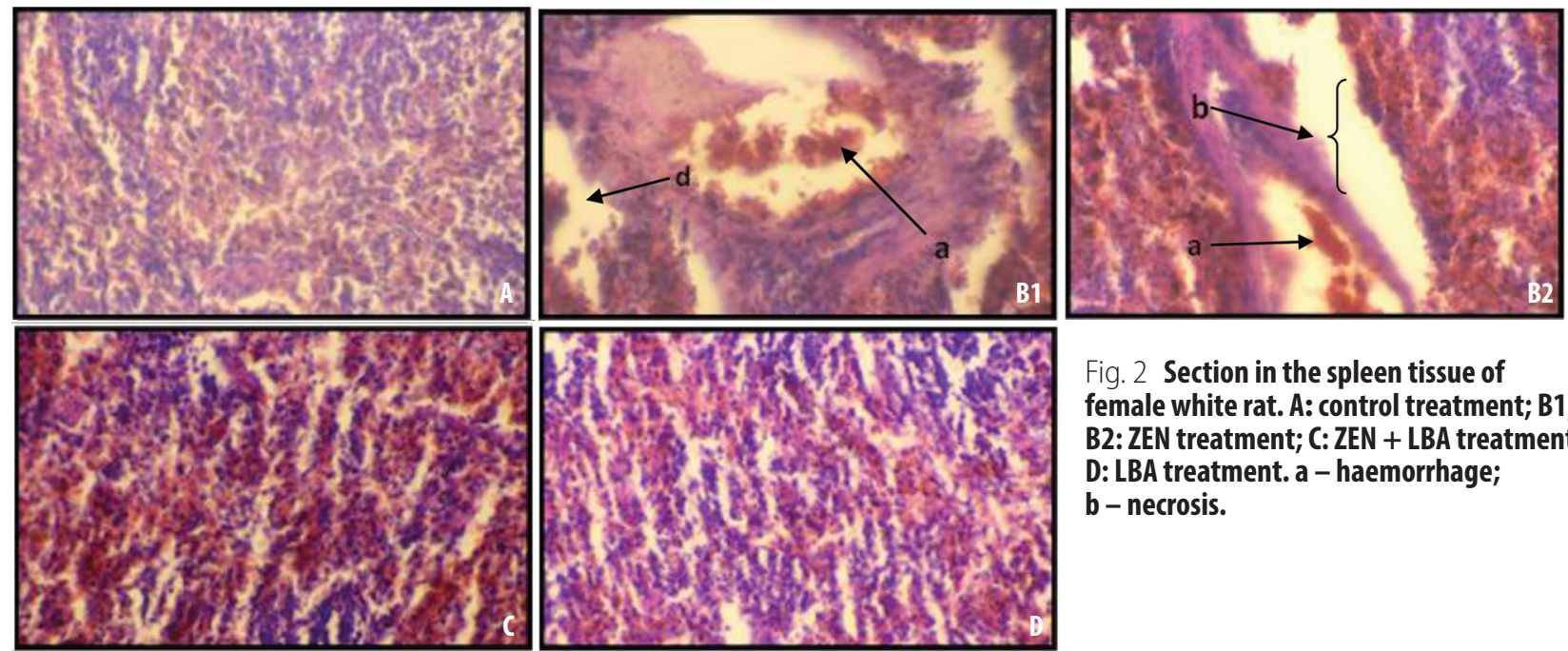

Fig. 2 Section in the spleen tissue of female white rat. A: control treatment; B1, B2: ZEN treatment; C: ZEN + LBA treatment; D: LBA treatment. a - haemorrhage; b- necrosis. 

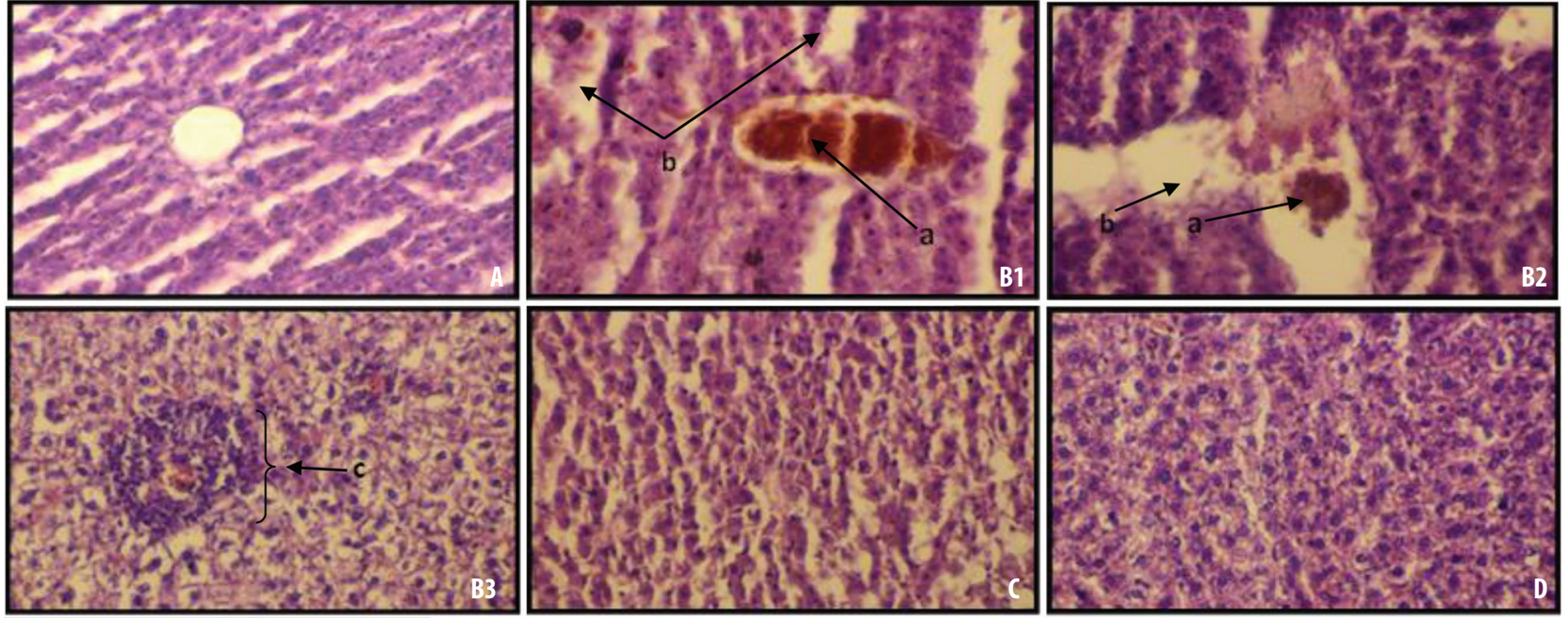

Fig. 3 Section in the liver tissue of female white rat. A: control treatment; B1, B2, B3: ZEN treatment; C: ZEN + LBA treatment; D: LBA treatment. $\mathrm{a}$ - vascular dilation and congestion; $\mathrm{b}$ - multifocal hepatocytes necrosis; $\mathrm{c}$ - focal aggregate inflammatory cells.
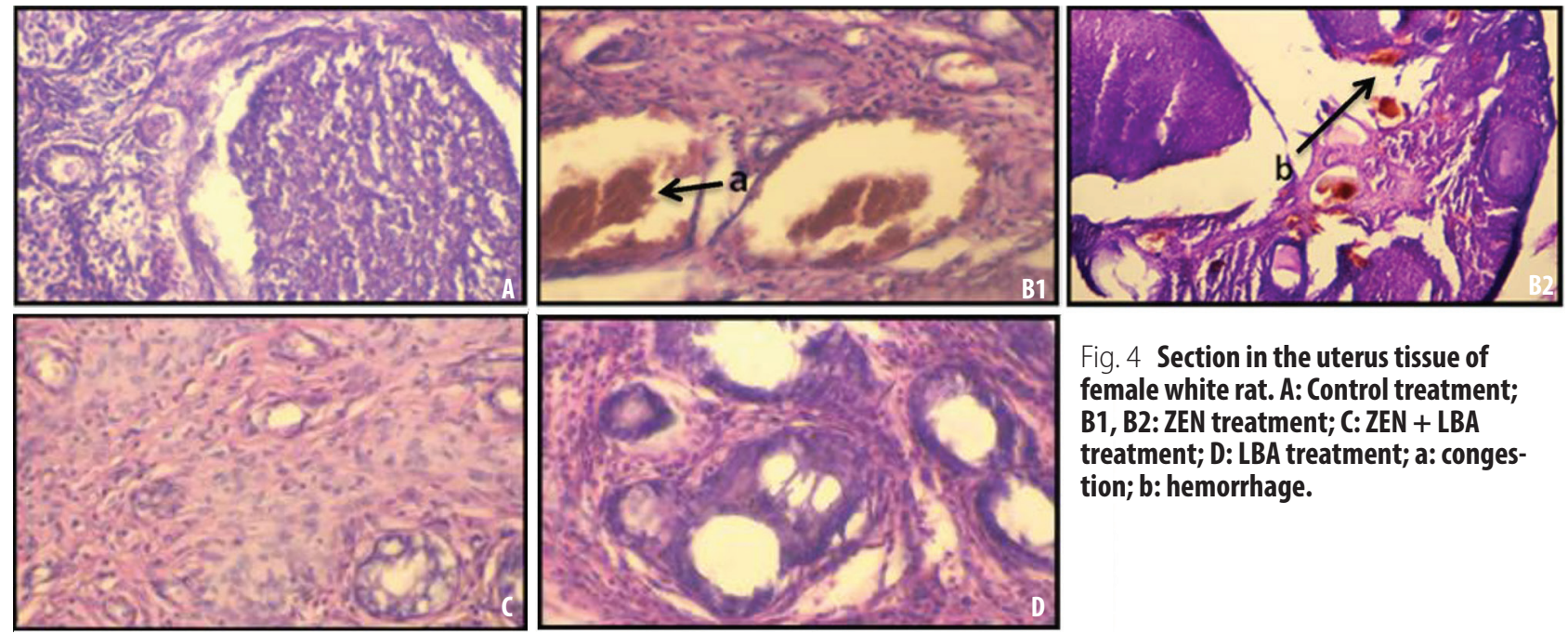

Fig. 4 Section in the uterus tissue of female white rat. A: Control treatment; B1, B2: ZEN treatment; C: ZEN + LBA treatment; D: LBA treatment; a: congestion; b: hemorrhage.

Verma $(2004)^{25}$ reported that Aspergillus flavus produced toxic metabolites that caused inflammation in renal glomeruli and bleeding.

Histological study showed that ochratoxin A caused pathological effects like thickening of vascular wall in kidney, while ochratoxin A caused severe micro abscess and necrosis in liver of animals. ${ }^{26}$

The mechanism of mycotoxin detoxification by bacteria includes:

\section{References}

1. Kuiper-Goodman T, Scott PM, Watanabe H. Risk assessment of the mycotoxin zearalenone. Regul Toxicol Pharmacol. 1987 Sep;7(3):253-306. doi: http://dx.doi.org/10.1016/0273-2300(87)90037-7 PMID: 2961013

2. Magan N, Olsen M. Mycotoxin in food. Cambridge, England: Wood Head Publishing Limited; 2002. p. 700

3. Collins TF, Sprando RL, Black TN, Olejnik N, Eppley RM, Alam HZ, et al. Effects of zearalenone on in utero development in rats. Food Chem Toxicol. 2006 Sep;44(9):1455-65. doi: http://dx.doi.org/10.1016/j.fct.2006.04.015 PMID: 16797818

4. Pillay D, Chuturgoon AA, Nevines E, Manickum T, Deppe W, Dutton MF. The quantitative analysis of zearalenone and its derivatives in plasma of patients with breast and cervical cancer. Clin Chem Lab Med. 2002 Sep;40(9):946-51. doi: http://dx.doi.org/10.1515/cclm.2002.166 PMID: 12435114
5. AL-Saadi TA. Integrated control of $A$. niger and A. parasiticus producing mycotoxins and contaminated apple and pears. [M.Sc thesis]. College of Agriculture/University of Karbala; 2014.

6. Sezer G, Abamüslüm $\mathrm{G}$, Nebahat $\mathrm{BO}$, Leyla V. Detoxification of aflatoxin B1 by bacteriocins and bacteriocinogenic lactic acid bacteria. Turk J Vet Anim Sci. 2013;37:594-601. doi: http://dx.doi.org/10.3906/vet-1301-31

7. Ishii K, Sawano M, Ueno Y, Tsunoda H. Distribution of zearalenoneproducing Fusarium species in Japan. Appl Microbiol. 1974 Apr;27(4): 625-8. PMID: 4825974

8. Scott PM, Lau PY, Kanhere SR. Gas chromatography with electron capture and mass spectrometric detection of deoxynivalenol in wheat and other grains. J Assoc Off Anal Chem. 1981 Nov;64(6):1364-71. PMID: 7309655 
9. Macfaddin JF. Biochemical tests for identification of medical bacteria. 1st ed. Baltimore: Williams \& Wilkins; 2000

10. Williams $P$, Lambert PA, Brown MR, Jones RJ. The role of the $O$ and $K$ antigens is determining the resistance of Klebsiella aerogenes to serum killing and phagocytosis. J Gen Microbiol. 1983 Jul;129(7):2181-91. doi: http://dx.doi.org/10.1099/00221287-129-7-2181 PMID: 6195306

11. Bancroft JD, Stevens A. Theory and practice of histological technique. New York: Churchill Living Stone; 1892. p. 117.

12. AL-Rawi KM, Khalaf AA. Design and analysis of agriculture experiments. Library for Printing and Publishing: University of Mosul, 1992.

13. Al-khafaji MF. Detection of OTA in some strategically grains varieties and possibility of bioremediation [M.Sc thesis]. Faculty of Education for Pure Science, University of Karbala, 2014

14. AL-Fatlawi BA. Morphology and molecular characterization of some microorganism associated with red and white meat domestic and possibility of controlling on it [PhD thesis]. faculty sciences, University of Kufa; 2014.

15. Kubena LF, Harvey RB, Corrier DE, HuffWE. Effects of feeding deoxynivalenol (DON, vomitoxin)-contaminated wheat to female white leghorn chickens from day old through egg production. Poult Sci. 1987 Oct;66(10):1612-18. doi: http://dx.doi.org/10.3382/ps.0661612 PMID: 3432188

16. Moura MA, Machado CH, Porfírio LC, Freire RB. Effects of ochratoxin a on broiler leukocytes. Bras cienc Avic. 2004 6(3):701-706. doi: http://dx.doi. org/10.1590/s1516-635×2004000300010
17. AL-Hashemi H. Bioremediation for Aflatoxin B1 and bifenthrin pesticide by using some species of bacteria [PhD thesis]. College of Education for Pure Sciences, University of Karbala; 2014.

18. Samuel AO, Olubukola O, Mathew AO. Hematological and immunological effect on chicken exposed to aflatoxin. Nigeria Veterinary World. 2009; 2(1):5-7.

19. Ali SA, Kazem SW. Study toxic effects of Bipolaris holmii in some vital system of white rat. Bio J Kufa University. 2012;4(2):20-8.

20. AL-Khalidy BA. Morphological and molecular of some Geotrichum ssp. isolates. Bio J Kufa University. 2012;1:148-58.

21. AL-Kelkali HJ. Evaluate the efficiency of some chemical and biological treatment in protection of potatoes from infection by Fusarium solani [M.Sc thesis]. College of Science University of Kufa; 2005.

22. Roder JD. Veterinary toxicology. USA: Butterworth-Heinemann; 2001. p. 73.

23. WHO Food Additives Series, No. 26, 1990. Toxicological evaluation of certain food additives and contaminants, nos 680-693 on INCHEM.

24. Al-Khalidy BA. Reported that the metabolic of G. canidium and G. pencillium caused abnormal changes in liver and kidney [PhD Thesis]. Faculty of Sciences, University of Kufa; 2010

25. Verma RJ. Aflatoxin cause DNA damage. International Journal of Human Genetics. 2005; 4(4): 231-36.

26. AL-Ghazaly MT. Study of toxicity Aspergillus niger which it is produced from ochratoxin A in vital system of albino rat [M.Sc thesis]. College of Education for Pure Science; 2014 